\title{
Price dispersion in Australian retail electricity markets
}

\author{
Simshauser and Whish-Wilson (2017) examined the restructured Victorian retail \\ electricity market and found it to be efficient as the marginal unit produced was sold at \\ marginal cost. This article extends their analysis of price dispersion by considering the \\ heterogeneous nature of electricity consumption when measured by volume sold ( $k W h$ ). \\ We find that customers on 'standing offer' tariffs use $18 \%$ less electricity than customers \\ on 'high discount' products, indicating the presence of market segmentation and implicit \\ second-degree price discrimination. Climate change policy and the emergence of new \\ technologies such as household solar PV, battery storage and home energy management \\ systems will create further price dispersion in Australian electricity markets due to even \\ greater product heterogeneity. We contend that policy makers will need to facilitate, \\ rather than prevent, both price and tariff structure dispersion with the objective of \\ improving consumer outcomes.
}

Keywords: electricity markets; price discrimination; energy policy JEL Codes: D40; D20; D22; L11

\section{Introduction}

Price discrimination in restructured retail markets is considered to be welfare enhancing by many energy economists. However, some stakeholders continue to question the fairness of consumers paying different prices for electricity as a homogenous product. This should not be a surprise given that electricity is an essential service and energy systems are not only an intricate network of physical and economic infrastructure but also a significant cultural system. There are large networks of business interests, geo-political stakeholders and carefully designed legal structures. These social and cultural networks took decades to build and are as important in explaining the inner functioning of the system as the economics, wires, steel and coal (Bakke, 2016, Ghazizadeh and Seifi, 2007).

Simshauser and Whish-Wilson (2017) established that deregulated Australian retail electricity markets were producing outcomes consistent with welfare enhancing price discrimination. Their study determined that Victorian price dispersion was high with 'Standing Offer' tariffs $10 \%$ above average cost and 'High Discount' tariffs at break-even prices (20\% less than average cost). The conclusion of Simshauser and Whish-Wilson (2017, p. 92) was: 'Efficient pricing requires the marginal unit produced to be priced at marginal cost and Victoria meets this criteria - but we identify an episode of inter-consumer misallocation due to high Standing Offers. We conclude policy initiatives designed to help firms shift vulnerable households from Standing Offer tariffs is desirable.' While competition was deemed to be effectively working for most customers, 'vulnerable customers' were deemed to be at risk and an appropriate targeted policy response was required. 
A key limitation of the Simshauser and Whish-Wilson study is the use of average consumption. The use of averages effectively implies a homogenous suite of consumer preferences. We have attempted to overcome this limitation by considering the different consumption profiles of customers on 'Standing Offer' and 'High Discount' products. By examining these consumption profiles we can better understand consumer preferences for investing time in 'shopping around' for the best discount. We can also glean insights into how retailers may be using second-degree price discrimination to provide implicit 'price discounts' for higher consuming customers.

The Australian electricity market is an important market to study for several reasons. There is sharp focus on the efficiency and fairness of the retail market. The Commonwealth Government has commissioned a review of retail electricity markets by the Australian Competition and Consumer Commission (ACCC). The Victorian Government has initiated a review chaired by the former Premier, John Thwaites (DELWP, 2017). Prominent 'think-tanks' have questioned the market's operation (see Grattan Institute, 2017, as an example) and Australia's Chief Scientist is conducting a review of the entire east-coast National Electricity Market (NEM) in response to blackouts in South Australia (Finkel et al, 2016). Australia also has amongst the highest uptake of household distributed solar PV generation of any market in the world and is expected to be among the leading markets for deployment of storage (see Orton et al, 2017). As such, the dynamics of 'retailing electricity' are likely to be advanced due to a focus on reducing emissions and further penetration of new energy technologies.

The purpose of this article is to extend the analysis of Simshauser and Whish-Wilson (2017) to consider heterogeneous customers. We have considered heterogeneity in two timeframes. Firstly, we have considered customers based on their different present consumption profiles. Secondly, we have considered how new products and services will allow unique customer demand profiles to be individually priced in the future. The article is structured as follows: Section 2 provides a brief recount of the existing literature that was well documented in Simshauser and WhishWilson (2017); Section 3 presents analysis on the consumption profiles of different Victorian consumers; the introduction of new energy products and services is considered in Section 4; with policy recommendations and concluding remarks provided in Section 5.

\section{Brief literature review}

Price discrimination has its origins in work presented by Pigou (1920). Stigler (1987) arguably has the best definition of price discrimination as where at least two (or possibly more) similar goods are sold at different prices relative to their marginal cost of production. Put simply, economists argue that prices are efficient where the marginal unit produced is priced at marginal cost (Varian, 1996). In electricity, such a statement can require greater consideration given that prices for electricity can reflect fixed charges, demand (i.e. $\mathrm{kW}$ ) and energy (i.e. $\mathrm{kWh}$ ) or a combination of the three. More generally, Robinson (1933) articulates that price discrimination relies upon firms being able to segment customers effectively, with two basic segmentations being strong (i.e. low elasticity, higher price) and weak (i.e. high elasticity, lower price). There are three basic forms of price discrimination:

- $\quad$ First-degree - a monopolist effectively prices each customer differently based upon their willingness to pay reflected through a downward sloping demand curve.

- $\quad$ Second-degree - non-linear pricing is utilised to provide discounts based on quantity consumed.

- $\quad$ Third-degree - market segmentation is utilised to base individual pricing for particular classes of customers on their willingness to pay (e.g. pensioner discounts at the cinema). 
The concept of price discrimination overcomes the simplistic notion of uniform pricing being set at marginal cost. Simshauser and Whish-Wilson (2017) articulate that the presence of non-trivial sunk costs in electricity systems necessitate the use of price discrimination. Given the very large upfront capital costs of building electricity generation and network infrastructure, prices cannot be uniformly set to the marginal cost (i.e. operating costs, fuel costs etc) of production. If prices were set in this way, the return on capital on sunk-cost infrastructure would be sub-optimal and new investment would not be forthcoming. Levine (2002) and Baumol \& Swanson (2003) explain that price discrimination is frequently how competitive firms recover their costs in a way that mirrors Ramsey ${ }^{1}$ pricing, but instead of facing a regulated revenue constraint, the broader market imposes a proximate revenue constraint on the rival firms. That is, prevailing prices include all separable costs, and some component of common fixed \& sunk costs in a way that is inversely related to the demand elasticity of segments served. And because the market (not a regulator) imposes the revenue constraint only efficient firms survive.

Simshauser and Whish-Wilson (2017) note that the price discrimination literature spans the range of markets with associated modelling bounded by numerous derivations of assumptions relating to the number of rivals, information, the size of customer segments, the ease of entry, discounts and customer poaching, mixed product bundles and other market structure characteristics. In competitive markets differential prices can fall either side of uniform price, or indeed, fall below the uniform price because ornate tariff structures are used by firms to attack rivals and steal market share and can produce what Corts (1998) describes as 'all out competition'. A key insight from Taylor (2003) is that when three or more competitors exist, firms earn economic rent on some customers but zero economic profit overall because they face strong incentives to price below-cost in some instances to poach rivals' customers. Consequently, marginal offers are not of themselves a sustainable equilibrium.

It is important to distinguish how price discrimination is utilised in competitive markets by individual firms. Much of the literature utilises the strong and weak segmentation theory discussed earlier. The theoretical uniform price is positioned between a higher price for the strong segment and a lower price for the weak segment (Holmes, 1989). With such pricing in place, and assuming that firms have dynamically shifting capabilities to segment (see Corts, 1998), there is an ability for firms to aggressively build market share. Discriminatory prices and ornate tariffs are used by firms to attack rivals. The presence of new energy technologies such as digital metering and analytics are enhancing the ability of electricity businesses to devise business models along these lines. The important assumption in the proposition above is that firms have differing capabilities and opinions on market segmentation (non-uniform segmentation) and actively seek to segment on the basis of the strong and weak components. Demonstrating this in practice is inherently difficult. However, it is also important to note that the alternative to price discrimination in restructured energy markets is regulated uniform pricing.

\footnotetext{
${ }^{1}$ Ramsey pricing was designed to be deployed in regulated monopoly industries as a means by which to recover common fixed and sunk costs in a least distortionary way, i.e. setting a high price in the relevant strong market and low price in weak markets essentially combining an inverse-elasticity rule with multi-part tariffs to recover infra-marginal costs for a given regulated revenue constraint. Ramsey pricing has long been regarded as a benign form of discriminatory pricing and preferable to uniform prices in declining cost monopoly industries. See Ramsey (1927).
} 
Corts (1998) has demonstrated that if firms are required to implement uniform pricing due to policy intervention, companies will naturally focus on strong market segments with a view to maximising profit. This has certain implications for policy makers in electricity markets.

Simshauser and Whish-Wilson (2017) discuss in great detail the 'working laboratory' situation in the UK as a result of Ofgem intervention in the electricity market to minimise price discrimination. They summarise the work of eminent economists (including Professors Yarrow, Vickers, Green, Littlechild, and Waddams Price) $)^{2}$ that reducing price discrimination is likely to reduce competition and have a detrimental impact on low-income customers.

There is general consensus within the literature that price dispersion increases as competition intensifies (see Borenstein and Rose, 1994; Dana,1998 and Stole, 2007). Firms effectively seek to utilise their market segmentation analytical capabilities to capture the market share of valuable customers. Theory and empirical research predicts a proliferation in the number and the complexity of products with intensifying competition. New products are how firms attract and 'poach' a rival's idle customer segments. It is not evidence of a market failure (Klein, 1993; Borenstein \& Rose, 1994; Levine, 2002; Baumol \& Swanson, 2003; Littlechild, 2014).This has certainly been the case in Australia where switching rates to new products in Victoria are among the highest in the world (see Grattan, 2017). Simshauser and Whish-Wilson (2017) state that, '..the presence of price discrimination is not, of itself, evidence of market power.' However, it is important to note that price dispersion is not necessarily evidence that market power (of some kind) does not exist either and issues of information asymmetry between electricity suppliers and their customers need to be addressed by policy makers in restructured energy markets (see Nelson and Reid, 2014 and Section 5 of this article).

\subsection{Australian electricity markets}

As noted earlier in this article, there is currently intense focus on the operation of the Australian electricity market. Some stakeholders are questioning whether retail electricity markets are delivering fair outcomes for consumers (see Ben-David, 2017, as an example). The ACCC is conducting a review on the operation of retail markets with retailer margins a key focus. It is important to note that the study by Simshauser and Whish-Wilson (2017) represents one of the few genuine attempts to study the impacts of price dispersion on consumer welfare. They established that the Victorian market met the definition of efficient pricing because the marginal unit produced was priced was priced at marginal cost.

\footnotetext{
2 For example, see Hviid \& Waddams Price (2012); Flores \& Waddams Price (2013); Pollitt \& Haney (2014); Littlechild (2014); Littlechild (2016).
} 
Figure 1: Components of an average electricity bill in Victoria

Total bill

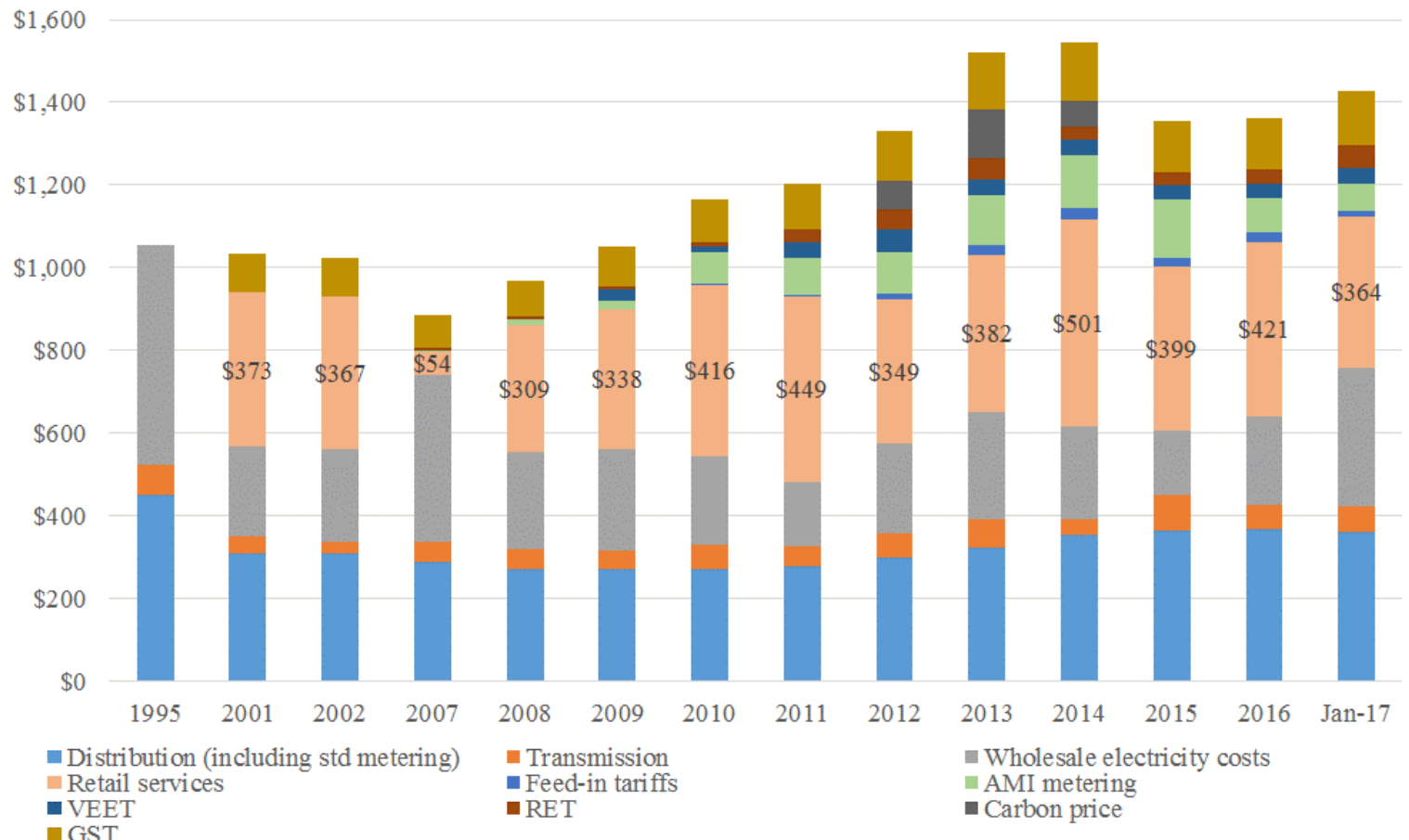

Source: Oakley Greenwood, 2017, p.6

Figure 2: Percentage components of an average electricity bill in Victoria

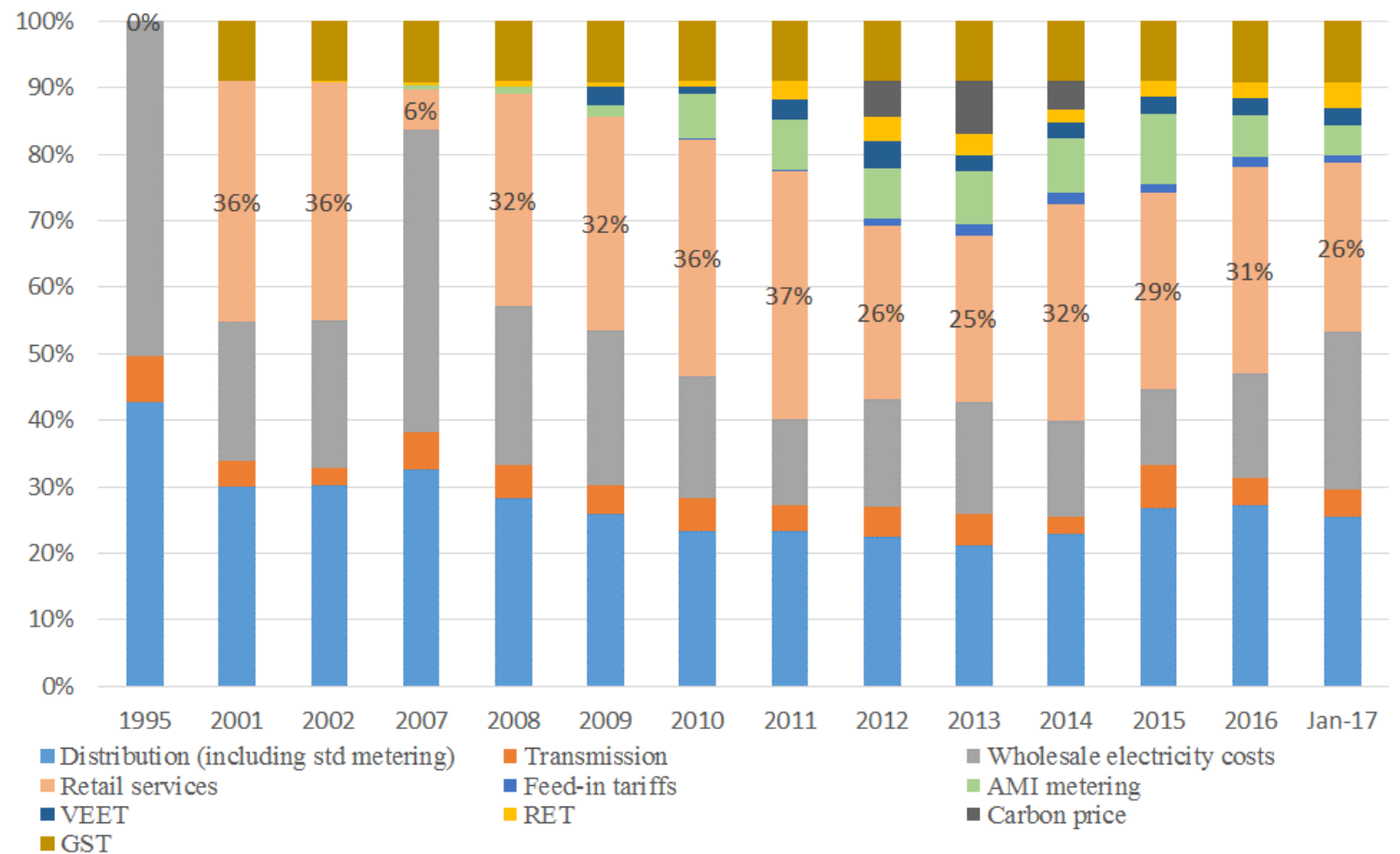

Source: Oakley Greenwood, 2017, p.6 
Figures 1 and 2 show the individual components of an average consumption electricity bill in Victoria. Interestingly, the retailing component has declined in the past few years as competition and switching has intensified. As first glance, this indicates that the price dispersion identified by Simshauser and Whish-Wilson (2017) may have led to a reduction in the retailer component of the bill. This would be consistent with the views they state are held by eminent economists (including Professors Yarrow, Vickers, Green, Littlechild, and Waddams Price), namely that price dispersion leads to increased competition which would in turn lead to, ceteris paribus, lower prices. ${ }^{3}$

However, the analysis in Figures 1 and 2 and the work of Simshauser and Whish Wilson (2017) is based upon average consumption. Furthermore, little evidence has been provided that customers are seeking discounts based upon a particular characteristic of their consumption or circumstances. Some stakeholders argue that information asymmetry is a key factor in the distribution of pricing and products among customers. In other words, it is an open question as to whether customer segmentation is being applied by firms based upon the weak and strong criteria. Section 3 seeks to build on the work of Simshauser and Whish-Wilson (2017) by assessing two key criteria of welfare maximisation: efficient pricing, whereby the marginal unit produced is priced at marginal cost; and whether there is evidence that customer segmentation is being utilised to justify price dispersion.

\section{Price dispersion for a relatively homogenous product}

Our first set of modelling replicates the work of Simshauser and Whish-Wilson (2017) by estimating average and marginal cost tariffs for Victoria. The results are presented in Figure 3. The first bar is the 2017 standing offer tariff (note in practice it is a two-part tariff but is presented as an average rate for comparison purposes). The second bar, titled Average Cost, is the industry average total cost of supply and has been derived from the Retail Energy and NEMESYS model utilised in the original Simshauser and Whish-Wilson (2017) study ${ }^{4}$. By our estimate, the split between fixed and variable costs is 70/30, respectively. The third bar, titled Marginal cost, is also derived from the models with two important changes. Firstly, wholesale supply costs rely on forward market prices, not modelled (and highly optimised) system costs. Secondly, retail supply profit margins have been purposefully set to zero. ${ }^{5}$ The final bar presents the marginal tariff in 2017 (again, it is a two-part tariff that has been converted to an average rate for ease of comparison).

\footnotetext{
${ }^{3}$ In reality, it is very difficult to articulate why prices move given the complexity of the supply chain. Figures 1 and 2 show the significant costs being incurred as a result of government policies such as the Victorian Energy Efficiency Target (VEET), carbon price, Advanced Metering Infrastructure (AMI: mandated smart meter rollout), and Renewable Energy Target (RET). In 2016/17, there has been a significant increase in forward wholesale electricity prices as a result of the closure of the Hazelwood power station and a debate exists about how such prices in wholesale markets should be attributed in an analysis such as this.

${ }^{4}$ Further information about the NEMESYS model is presented in Simshauser and Whish-Wilson (2017).

${ }^{5}$ We note the marginal cost estimate is defined from a retailer's standpoint and includes the full cost of the network component rather than the network's marginal rate of supplying a further unit.
} 
Figure 3: Victorian Standing Offers, average cost, marginal cost and marginal tariff

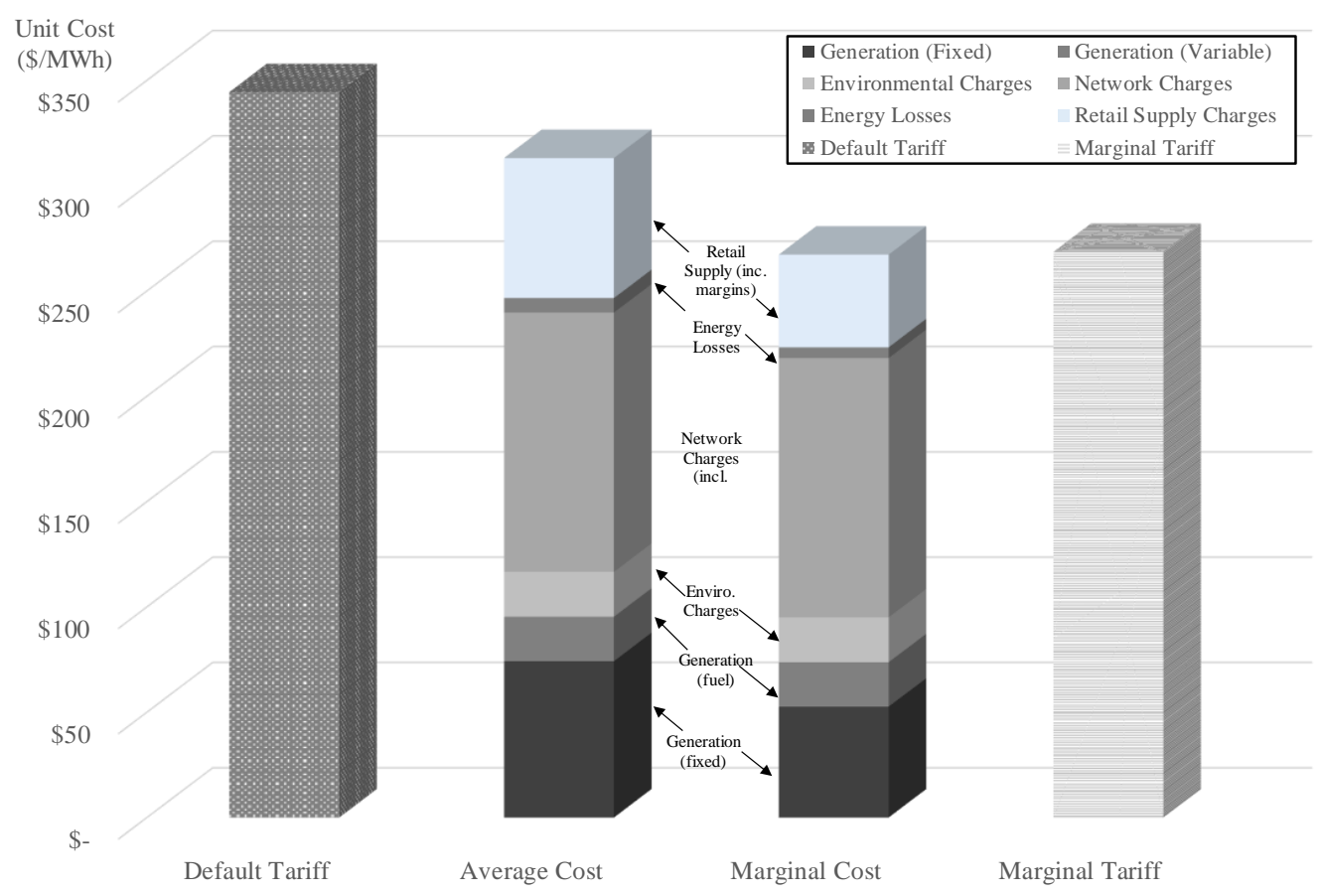

Figure 4: Victoria average cost, marginal cost and retail offers ( $4000 \mathrm{kWh}$ per annum)

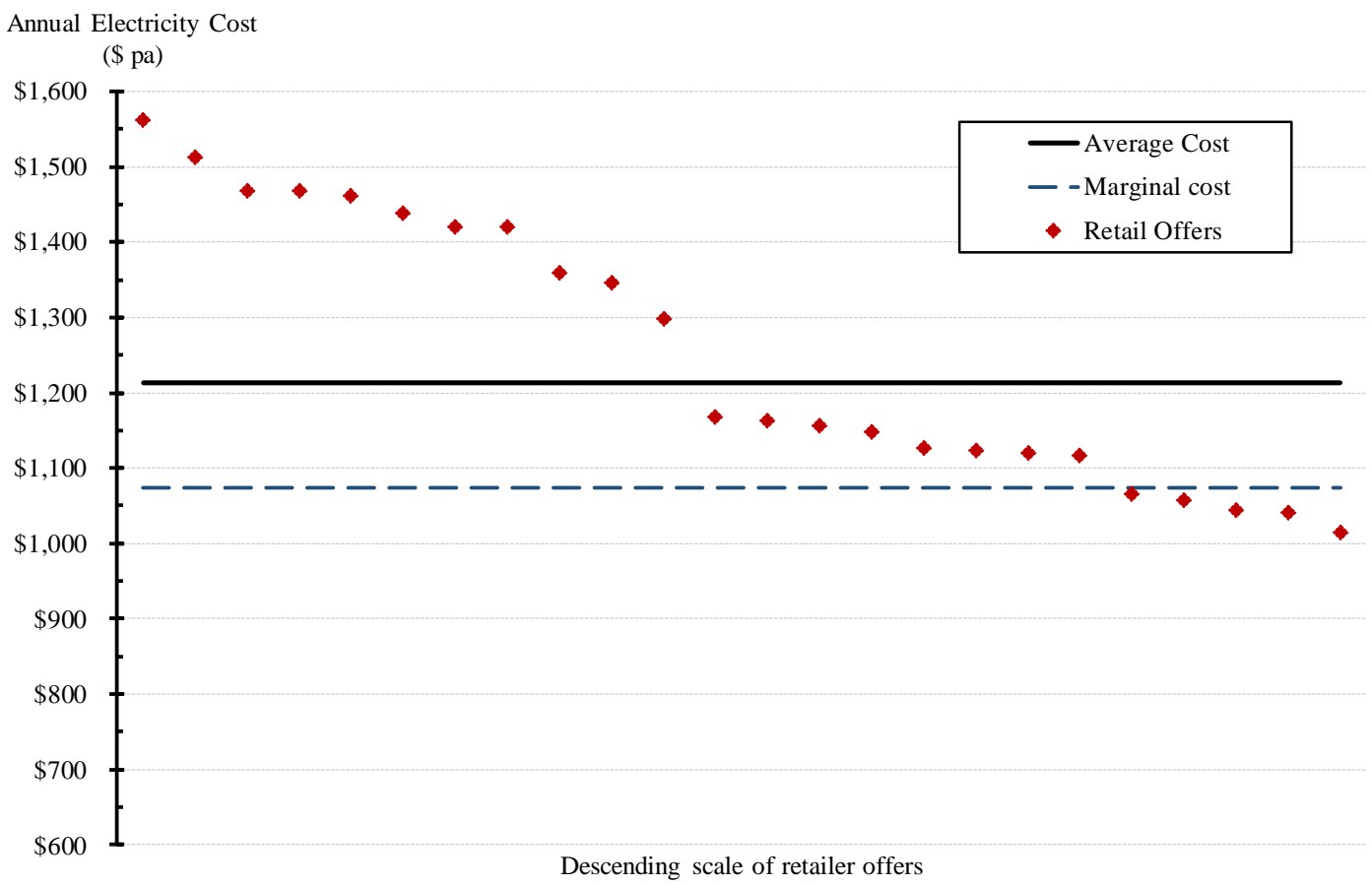


Figure 4 presents the spread of offers for Victoria represented by their annual cost. ${ }^{6}$ Note the two 'cost' lines represent our modelled annual estimates of Average Cost and Marginal Costs from Figure 3. Average Cost is represented by the solid line while Marginal Cost is represented by the dashed line. Diamond markers represent Standing Offers and best routine discount offers of the active retailers in descending order. There is substantial dispersion in offer prices and above all, the annual bill size of the marginal offer approximates our estimate of the annual marginal cost of retail supply. The work of Borenstein (2009) and Ito (2012) provides strong evidence that consumers, uncertainty about their consumption, actually respond to average price rather than marginal price. Based on this research, our analysis using annual charges (or average prices) demonstrates that the first of the two key welfare maximisation criteria is met: the marginal unit sold is priced at marginal cost. ${ }^{7}$

Figure 5 provides a summary of market offers by generic 'offer blocks'. The blocks represent the differential between active retailer Standing Offers and the lowest market offer available. The height of each block represents the range or spread of prices available under the product offering in question ( $\$ / \mathrm{pa})$ while the length of the blocks roughly indicates the percentage of total customers accessing each product. It shows that around approximately $56 \%$ of customers are currently paying prices below our estimate of average cost. This has increased substantially over the last 5 years as highlighted in Appendix 1.

Figure 5: Average cost, marginal cost and tariff dispersion

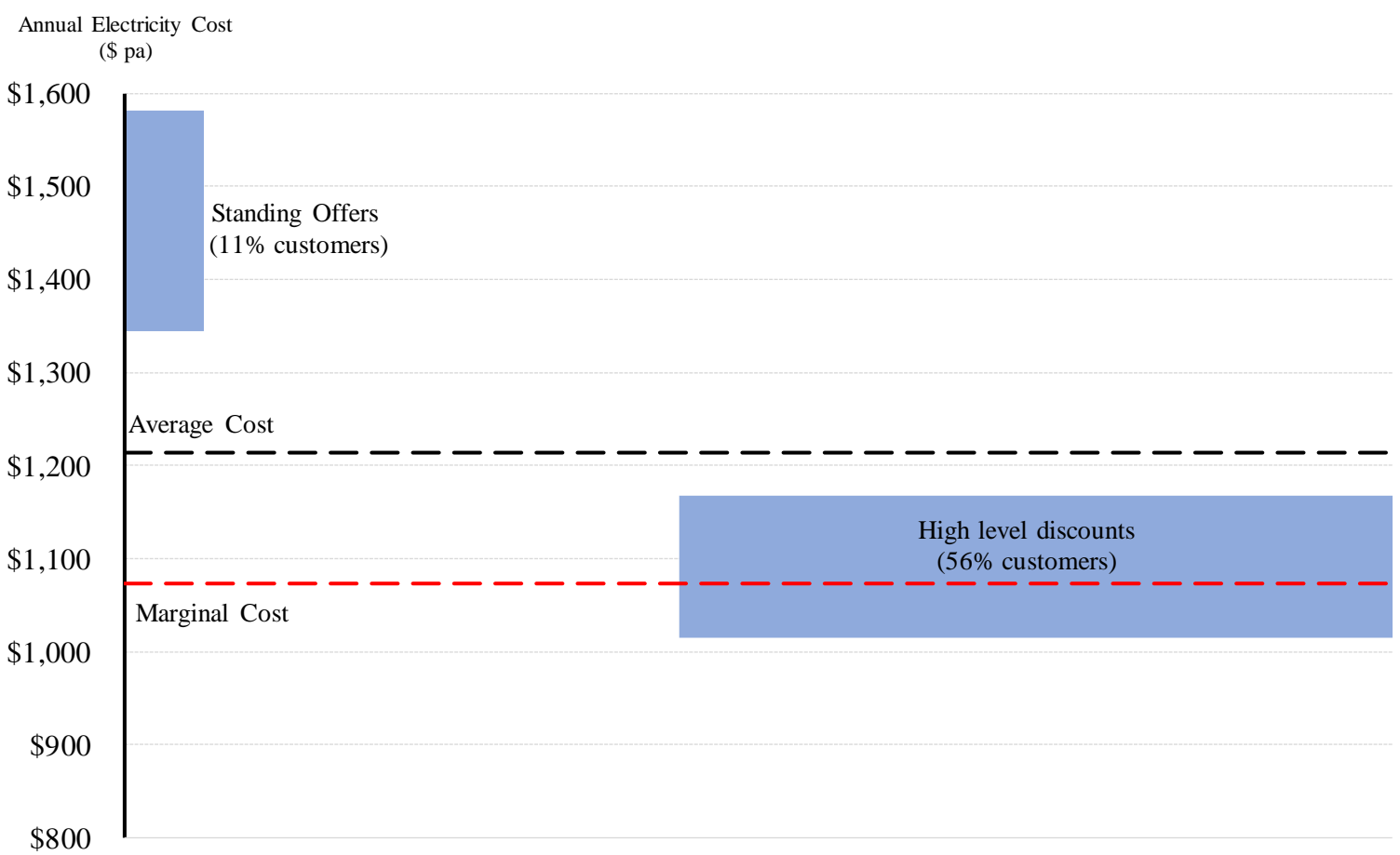

Distribution of Customer Discounts

\footnotetext{
6 This figure is not a demand curve but is instead a representation of different offers (annualised) in the market.

${ }^{7}$ The marginal cost is actually in c/kWh (with a two part tariff) but the annual bill estimates have a correlation with the marginal rates of additional supply of greater than 0.85.It is therefore appropriate to use the annual charges in our analysis (see Ito, 2012).
} 
A key limitation of Simshauser and Whish-Wilson (2017) is their assumption about customer homogeneity. Their original analysis assumes average customer consumption of 4,200 $\mathrm{kWh}$ pa for a Victorian household, although we have used 4,000 $\mathrm{kWh}$ pa in the analysis above. However, when it comes to consumption, customers are far from homogenous (see the important contribution by Reiss and White, 2005). In fact, consumption represents an ideal way to examine customer heterogeneity in relation to electricity. Firms may have an ability to segment on the basis that consumption levels are an indicator of strong and weak market segments. Greater consumption levels may indicate high elasticity/low price (weak) and lower consumption levels may be associated with low elasticity/high price (strong). Such segmentation may lead firms to offer different prices and consumers may benefit from a form of implicit second-degree price discrimination (i.e. volume discounts). Firms are effectively assessing a customer's willingness to 'shop around' based upon the potential savings - with greater potential monetary savings being a function of greater consumption. ${ }^{8}$

In practical terms, low consumption may be associated with 'essential service' consumption (e.g. lighting, cooking, hot water) and high consumption may be associated with more discretionary usage (e.g. pool pumps). High consumption may also be a function of greater numbers of people in the home (see IPART, 2015; and Simshauser and Nelson, 2014). Previous studies have found that high consumption households are often in the 'family formation' demographic group where lower prices are actively sought out by consumers due to overrepresentation of 'customer hardship' (see Simshauser and Nelson, 2014). By examining different customer consumption profiles and market engagement, it is possible to infer whether the market is functioning through customers allocating time to select the most appropriate energy deal based upon their unique circumstances.

To overcome the focus on average consumption, we utilised a similar billing data set to that used in Simshauser and Whish-Wilson (2017). Ideally it would be possible to list all customers and the price they are paying but such data would require knowledge of every customer contract. To overcome this complexity, we have examined the consumption profiles of customers on 'standing offer' and 'high discount' products. ${ }^{9}$ Mean consumption for each sub-set of customers is presented in Figure 6.

\footnotetext{
${ }^{8}$ From the customer's perspective, high consumption implies that the value ascribed to time spent assessing energy market deals is greater.

91000 'standing offer' (higher priced default product) and 1000 'high discount' (the largest discount offer provided by AGL Energy Ltd) customer load profiles were extracted at random to provide a sample. See Appendix 1 for a distribution of AGL customer discounts in Victoria. The number of customers on higher discount products has increased over the past few years.
} 
Figure 6: Mean daily consumption of 'standing offer' and 'high discount' Victorian households

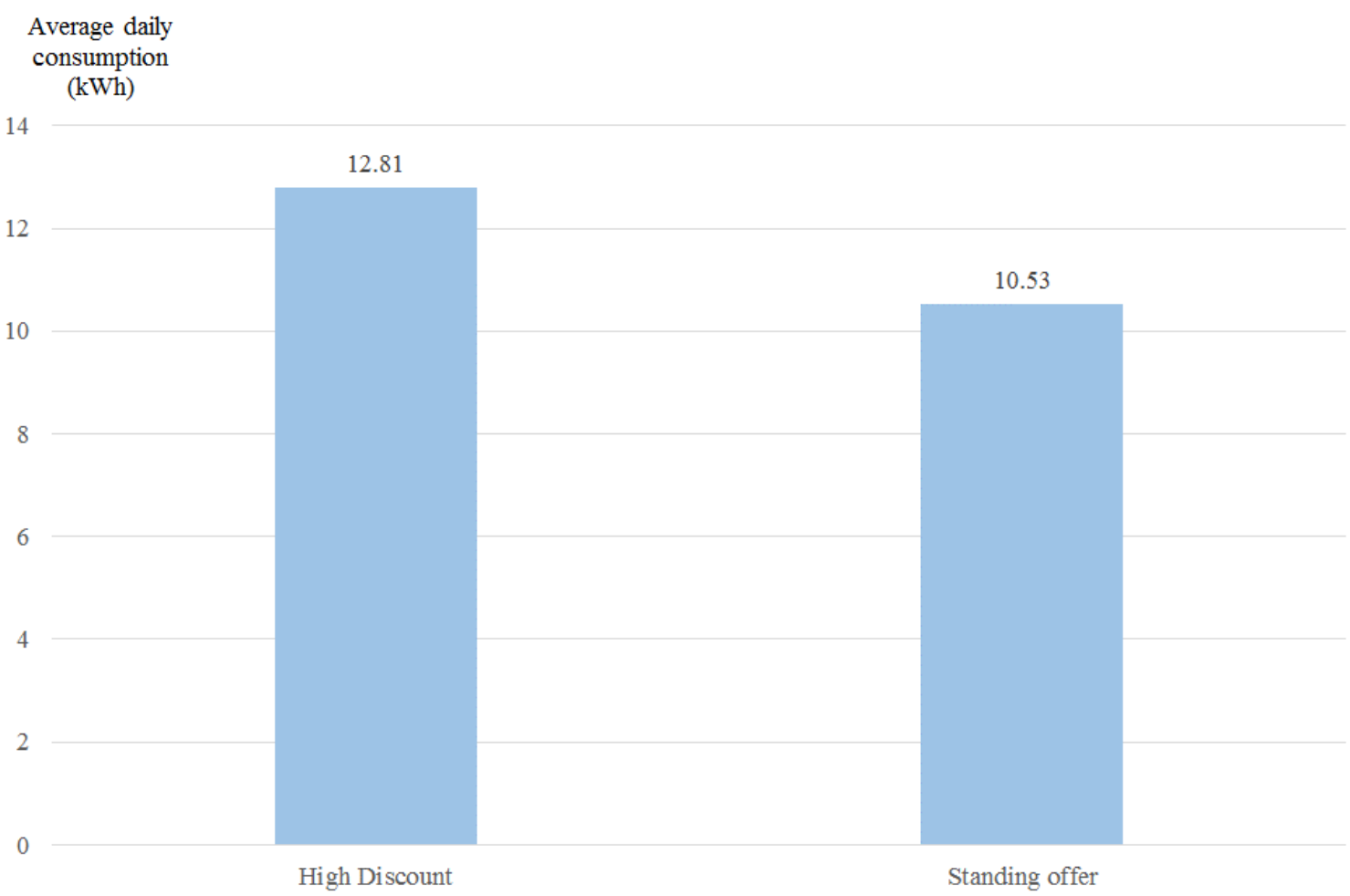

Source: Aggregated customer data from AGL billing system

Figure 6 shows that mean consumption for 'high discount' customers is $4,675 \mathrm{kWh}$ per year or around $22 \%$ higher than 'standing offer' customers $(3,843 \mathrm{kWh})$. This is indicative of seconddegree price discrimination being utilised by firms to provide volumetric discounts to customers that value 'shopping around'. Customers on 'standing offers' use around $8 \%$ less energy than the average customer and as such may not value the potential savings available from shopping around as much as the time that would be spent doing so. On the other hand, customers on the 'high discount' product consume approximately $12 \%$ more than the average customer and we can therefore infer that such customers are more willing to spend time assessing different products given the substantial savings potential due to higher consumption. ${ }^{10}$

\footnotetext{
${ }^{10}$ A reviewer made the important observation that price and consumption findings could be related to price elasticity rather than price dispersion. Several studies indicate that household demand for electricity is highly price inelastic. See NIEIR (2002); ESC (2002); ESCOSA (2004); AUSGRID (2015). As an example, AUSGRID (2015, p. 7) states that, 'to elicit a 4\% drop in demand for electricity, price changes in the order of $30-40 \%$ would be required.'
} 
Figure 7: Mean daily consumption profile of 'standing offer' and 'high discount' Victorian households

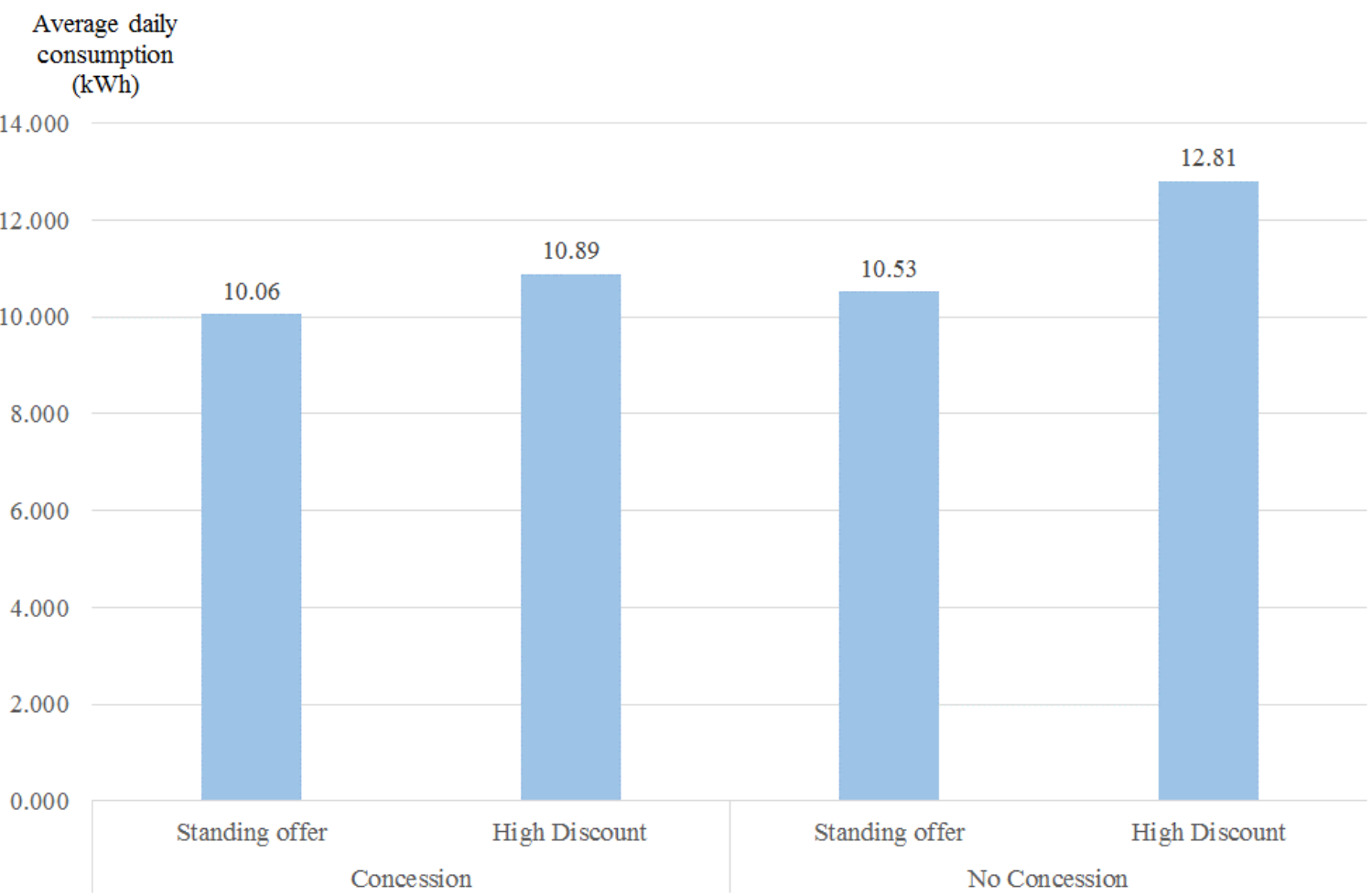

Source: Aggregated customer data from AGL billing system

Consumption for a further subset of customers receiving concessions rebates is shown in Figure 7 with associated load profiles presented in Figure $8 .{ }^{11}$ There is a much lower spread of consumption between 'standing offer' and 'high discount' customers that are receiving a government concession (around 8\%), with lower consumption overall (a finding consistent with Simshauser and Downer, 2016). There is less evidence that implicit second-degree price discrimination is being utilised for this customer segment. That said, given that concessions are often used as a 'proxy' for vulnerability it is important that policy makers consider whether there is a difference in active participation in the market by this customer cohort. This could be explored in subsequent research.

\footnotetext{
${ }^{11} 1000$ 'standing offer' and 1000 'high discount' concessions customer load profiles were extracted at random to provide a sample. In Victoria, the Annual Electricity Concession is available to concession cardholders and involves a discount of $17.5 \%$ on household electricity bills. Eligibility requires one of the following: Pensioner Concession Card; Health Care Card; or DVA Gold Card (veterans).
} 
Figure 8: Load profiles of customer segments

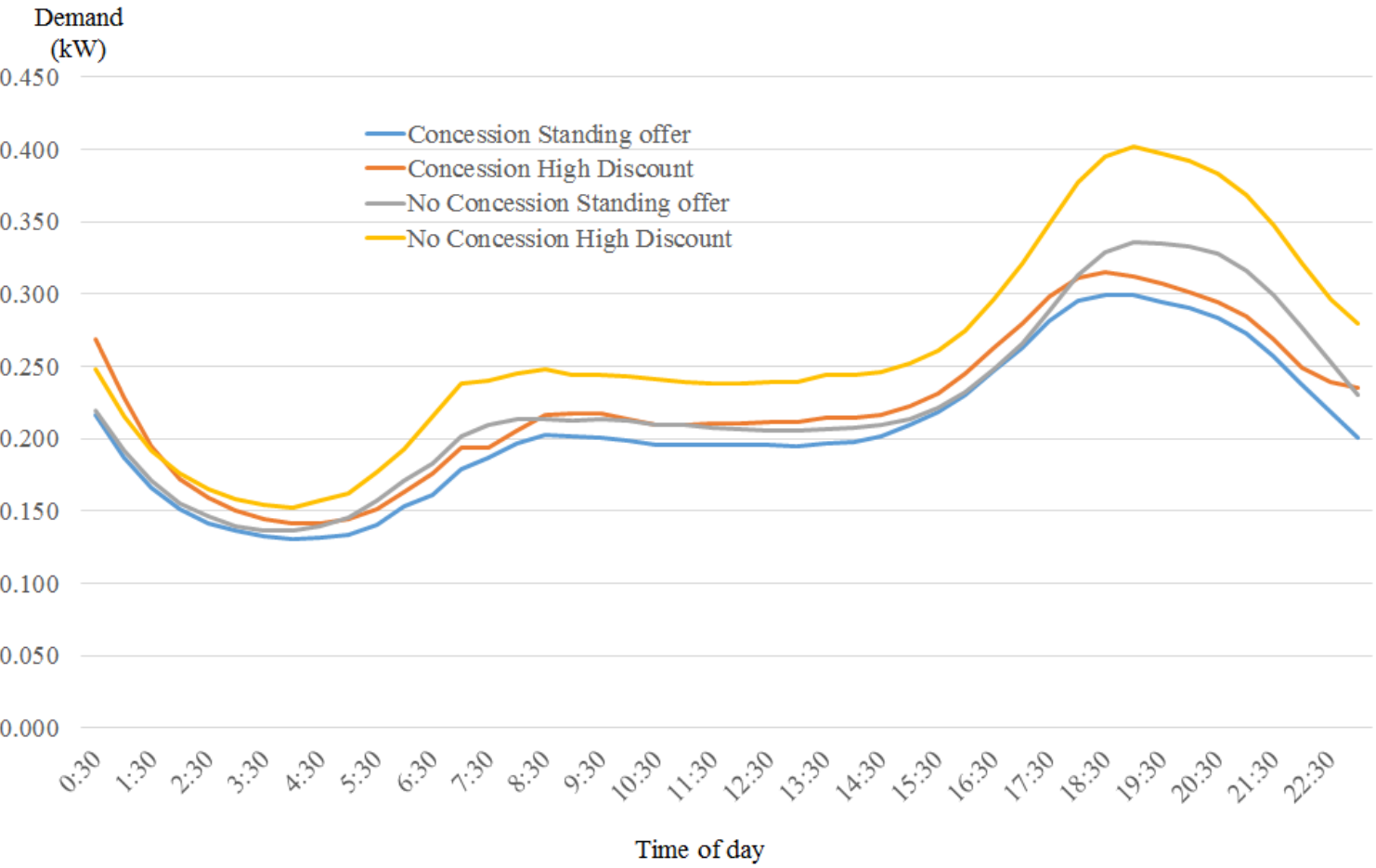

Source: Aggregated customer data from AGL billing system

Figure 9: Frequency distribution of customers by consumption ${ }^{12}$

No.

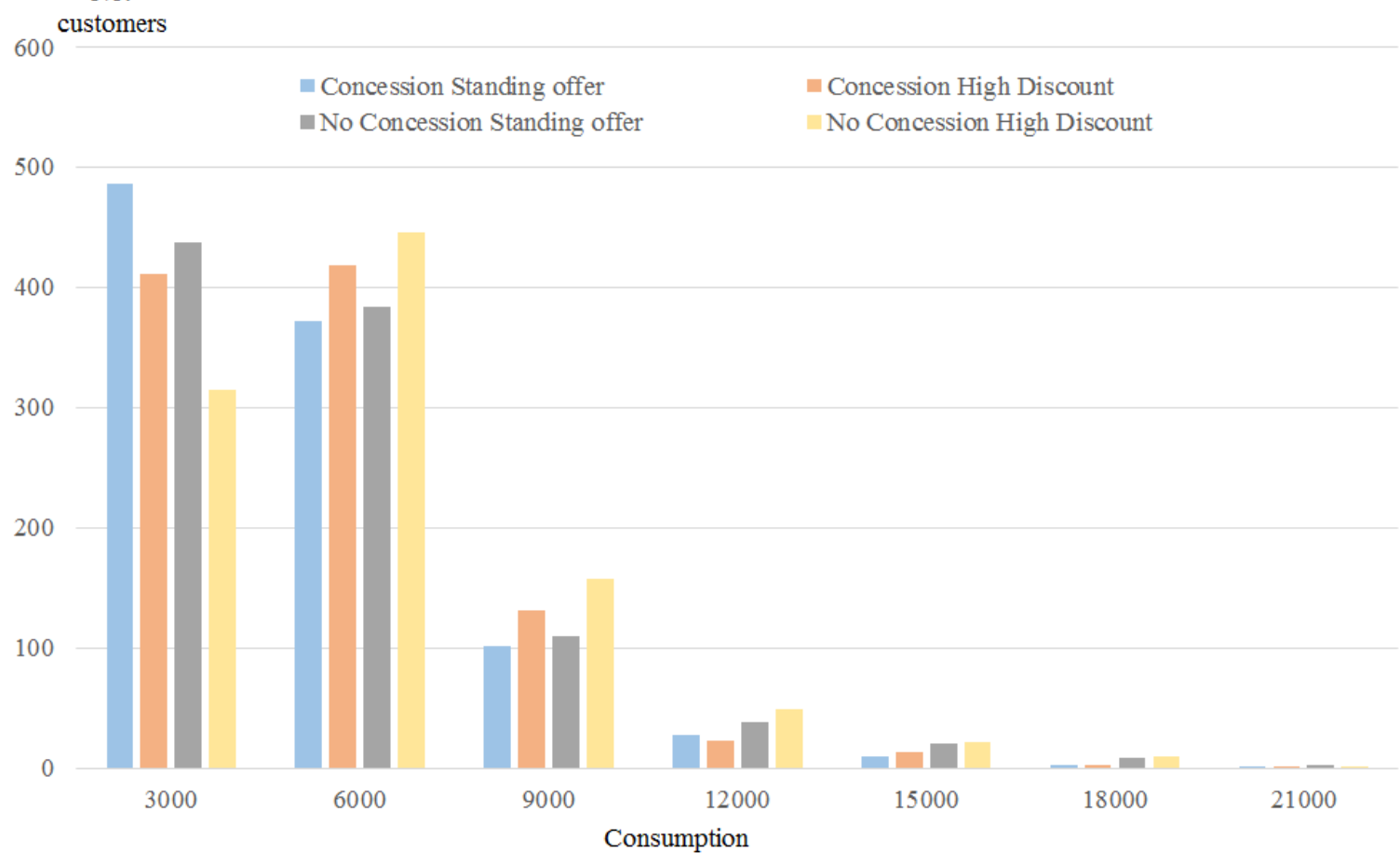

Source: Aggregated customer data from AGL billing system

\footnotetext{
12 The average mean deviation for the groupings are: concession standing offer -5.11 ; concessions high discount -5.04 ; nonconcession standing offer -6.03 ; non-concession high discount -6.02 . The standard deviation for the same groupings are $6.78,6.81$, 8.40 and 8.15 respectively. Mean-difference tests for the groups are presented in Appendix 2.
}

Page 12 
The frequency distribution of customers by consumption is presented in Figure 9. Consumption is clearly an important variable in explaining resultant price dispersion. Customers with higher consumption are overrepresented on 'high discounts' while customers with lower consumption are overrepresented on 'standing offers'. This indicates that consumers understand the positive correlation between monetary savings (measured in reduced billed expenditure) and consumption. ${ }^{13}$ Consumers are also likely to understand that, in some scenarios, the costs of spending time to find the best electricity contract, may outweigh any resultant savings given a lower consumption profile. Implicitly, second-degree price discrimination is being pursued.

An important policy recommendation of Simshauser and Whish-Wilson (2017) related to the need to shift vulnerable customers off standing offer tariffs. Electricity supply is an 'essential service' and energy companies have an obligation to ensure that vulnerable customers are on an appropriate product. Our data set shows that Victorian customers on AGL's hardship program use around $40 \%$ more electricity than average. Entry into the hardship program is not based on whether or not a customer holds a concession card. It is open to any customer experiencing a period of financial hardship which is causing them difficulty paying their energy bill. Of the approximately $25 \%$ of AGL customers receiving a concession rebate, less than $3 \%$ are participating on the hardship program. About $45 \%$ of customers participating on the hardship program do not receive a concession rebate. Thus interventions to protect vulnerable households must be cognisant of the risks of using certain proxies, such as receipt of a concession rebate, as a qualifying criterion. This has important public policy implications which will be presented in Section 5.

\section{Price dispersion for a heterogeneous suite of products and services}

The literature and supporting empirical analysis in the preceding section recognises that price dispersion for a largely homogenous product tends to be welfare enhancing. The view of electricity supply as a homogenous good meeting a largely consistent consumer need is being upturned by ongoing developments in the cost, availability and capabilities of distributed energy technologies. The emergence of these technologies is being accompanied by a proliferation of new entrants with novel business models crafting innovative energy service offerings for customers. This section explores this evolution and the implications for price dispersion as an indicator of competition in retail energy markets.

Since solar PV systems first entered the Australian consumer market a decade ago, some 17\% of Australian households now produce their own electricity via a rooftop solar PV system. In Queensland and South Australia, this figure exceeds 25\% (AEC, 2016). There are more than 1.65 million small-scale installations across Australia (AEC, 2017). By substantially modifying a customer's residual demand profile, together with their overall grid energy requirements, this development alone sees the emergence of a class of customers whose needs and preferences will not always match those of the 'traditional' energy customer. Customers with rooftop solar become interested in new aspects of the retail offers available to them - such as the magnitude of feed-in tariff, the relative weighting of fixed versus variable components and the timing of, and differential between, peak and off-peak rates.

\footnotetext{
${ }^{13}$ Our policy recommendations in Section 5 discuss the importance of these findings in the context of the 'demographic cohorts' most likely to 'shop around'. Simshauser and Nelson (2014) found that the 'family formation' demographic is likely to benefit the most from deregulated markets due to its high consumption and low-income per person in the home. The results of our analysis indicate that this demographic (represented by higher average consumption) may in fact be the primary beneficiary of price dispersion. Some may argue that this is a positive outcome.
} 
A second 'wave' of distributed energy technologies are now entering the Australian consumer market with even more profound implications for the heterogeneity of consumer needs and preferences, as well as the volume and diversity of enterprises operating in the market and the range of energy services on offer. Behind-the-meter energy storage is expected by some analysts to grow exponentially over the next two decades. Bloomberg New Energy Finance (2017) anticipates that $37 \mathrm{GWh}$ of energy storage will be installed behind-the-meter by 2040 , with $53 \%$ of this installed at residential customer premises (see Table 1). This equates to $24 \%$ of residential buildings having a storage system (BNEF, 2017). Other technologies that are currently on the periphery but expected to see increasing take-up include electric vehicles, smart appliances and sophisticated home energy management systems.

Table 1: Cumulative storage installations by sector ('000 systems)

\begin{tabular}{c|c|c|c}
\hline Sector & 2020 & 2030 & 2040 \\
\hline Residential & 101 & 984 & 2,540 \\
Commercial & 9 & 74 & 112 \\
Industrial & 0 & 7 & 73 \\
\hline
\end{tabular}

Firms are also beginning to deploy sophisticated software platforms that enable the real-time performance monitoring of distributed energy systems installed behind-the-meter at a residential premises, and the ability to deploy those systems either individually or as part of a fleet in response to centrally transmitted commands. This accurate performance monitoring and potential for aggregated and dynamic response offers an abundance of innovation potential - from enabling peer-to-peer energy trading and the participation in large-scale Virtual Power Plants, to the development of highly dynamic and efficient embedded networks or micro-grid systems.

Alongside the 36 'traditional' licensed retailers operating in Victoria ${ }^{\mathbf{1 4}}$ and the 59 operating across the remainder of the NEM, ${ }^{15}$ 'alternative' license-exempt energy sellers are proliferating. A prime example is firms selling energy to customers from a solar PV system installed behind-the-meter at the customer's own premises under what is known as a 'power purchase agreement'. Another very common form is firms reselling energy within an embedded network. Over 2500 current licence exemptions have been granted by the Australian Energy Regulator, ${ }^{\mathbf{1 6}}$ a figure which under-represents those in place across the NEM since Victoria operates its own licencing and exemption system.

At its core, the evolution of technology is facilitating the provision of products and services that allow customer consumption heterogeneity to be uniquely priced in 30-minute increments. The price dispersion and segmentation identified in Section 3 can be deployed 17,520 times in a year. From the customer's perspective, technology developments and increased product and service competition mean more choice than ever before. For example, they may preference online and digitally enabled service interactions, tools that enable them to closely monitor usage, and/or the availability of flexible payment options. They may choose to combine grid supplied and distributed energy sources, and/or expect to be able to share energy and share in value streams beyond the home (such as network and wholesale values).

\footnotetext{
${ }^{14}$ Essential Services Commission of Victoria, List of current Electricity Retail Licences, http://www.esc.vic.gov.au/project/energy/2075-licensing/ accessed online on 12 April 2017.

15 Australian Energy Regulator, Public register of authorized retailers, https://www.aer.gov.au/retail-markets/authorisations/publicregister-of-authorised-retailers-and-authorisation-applications?f[0]=field acce aer status\%3A7 accessed online on 12 April 2017.

${ }^{16}$ Australian Energy Regulator, Public register of retail exemptions, https://www.aer.gov.au/retail-markets/retail-exemptions/publicregister-of-retail-exemptions?page=1\&f[0]=field_accc_aer_status\%3A7, accessed online on 12 April 2017.
} 
In Australia, network tariffs (and the retail tariffs that overlay them) have typically been comprised of a fixed 'service to property' charge and a volumetric component charged per unit of energy $(\mathrm{kWh})$ consumed. However, in recognition of the technology evolution underway (and the fact that network costs are driven more by peak demand than total consumption), regulators have required distribution businesses to introduce more cost-reflective network tariffs. These typically involve the introduction of a third component to a customer's tariff: a demand charge which varies month-on-month dependent on the household's peak energy consumption during the designated peak demand window (typically $3-8 \mathrm{pm}$ ). The tariffs being offered by networks are summarised in Table 2. 
Table 2: Cost reflective network tariffs from 2017

\begin{tabular}{|c|c|}
\hline Network business & Proposed tariff \\
\hline Ergon & Opt-in Seasonal Time-of-Use Energy and Seasonal Time-of-Use Demand tariffs \\
\hline Energex & Opt-in Demand tariff includes Hot Water Tariff for Demand customers. \\
\hline Ausgrid & $\begin{array}{l}\text { Opt-in Time-of-Use tariffs. From } 1 \text { July } 2018 \text {, all new customers assigned to Time-of-Use tariffs with opportunity to opt- } \\
\text { out to a transitional tariff. All existing customers with digital metering to be assigned to this transitional tariff on } 1 \text { July } \\
2018 \text {. }\end{array}$ \\
\hline Essential & $\begin{array}{l}\text { Time of Use tariff default for new customers, new Solar PV installations and metering upgrades. Opt-in to Demand-based } \\
\text { tariffs also available. }\end{array}$ \\
\hline Endeavour & $\begin{array}{l}\text { Opt-in Time of Use tariffs. All new customers with interval meters assigned to Time-of-Use tariffs from } 1 \text { July } 2018 \text { on } \\
\text { opt-out basis. }\end{array}$ \\
\hline ActewAGL & $\begin{array}{l}\text { Time-of-Use tariff default for all new residential and small business customers. Small business customers can opt-in to } \\
\text { Demand tariffs. Possible gradual introduction from } 1 \text { December } 2017 \text { of residential demand tariff. }\end{array}$ \\
\hline $\begin{array}{l}\text { Citipower. } \\
\text { Powercor, United } \\
\text { Energy, Jemena, } \\
\text { Ausnet }\end{array}$ & $\begin{array}{l}\text { Opt-in residential Demand Tariffs (not available in Ausnet service area until 2018). Opt-in Demand tariffs for all small } \\
\text { business customers consuming <60 MWh pa. United and Jemena: Demand tariffs mandatory for small businesses } \\
\text { consuming }>60 \mathrm{MWh} \text { pa. Powercor, CitiPower and Ausnet: transitional Demand tariff mandatory for small business } \\
\text { consuming }>60 \mathrm{MWh} \text { pa. Cost reflectivity of the transitional tariff will increase between } 2017 \text { and } 2022 \text {. }\end{array}$ \\
\hline $\begin{array}{l}\text { South Australia } \\
\text { Power Networks }\end{array}$ & $\begin{array}{l}\text { Opt-in cost-reflective residential Demand tariff. Opt-in 'fully' cost-reflective demand tariff for small business customers. } \\
\text { Mandatory assignment to transitional Demand tariff ( } 50 \% \text { cost reflective Demand) for new 3-phase customers and } \\
\text { progressive increases in cost-reflectivity until } 2022 .\end{array}$ \\
\hline
\end{tabular}

Source: Distribution network businesses tariff statement 
Figure 10: Average 'hot day' residential load profile with $3 \mathrm{~kW}$ solar PV and $6 \mathrm{kWh}$ energy storage

$\begin{aligned} & \text { Energy demand } \\ & \mathrm{kW}\end{aligned}$
Supply from the grid
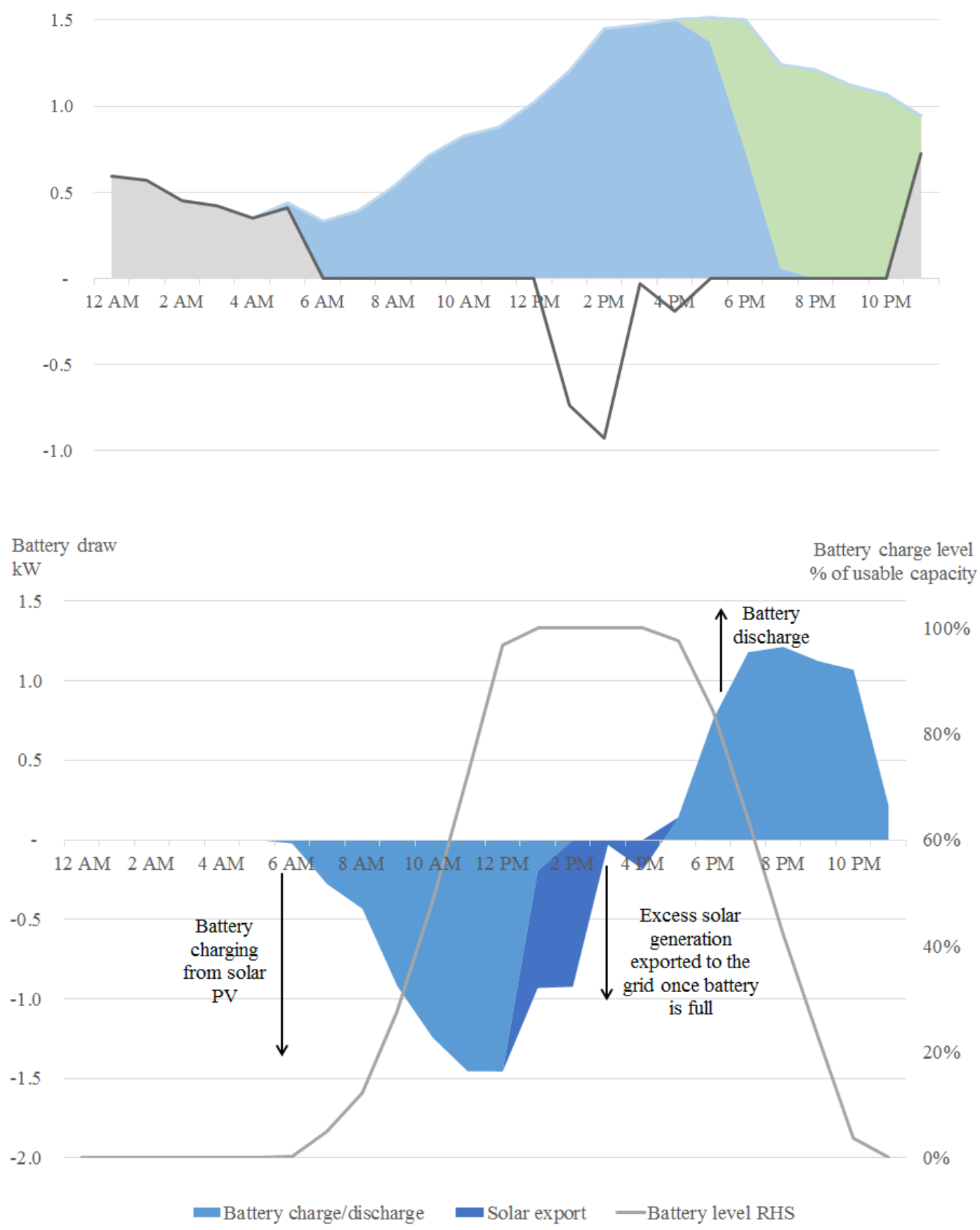
The introduction of new demand-based tariffs alters the economics of new energy technologies substantially. Figure 10 demonstrates this by highlighting the impact of installation of a $3 \mathrm{kw}$ solar PV plus battery energy storage system with $6 \mathrm{kWh}$ useable capacity ${ }^{17}$ on an average household load profile. The solar PV system is configured to first charge the battery, with any surplus exported to the grid. The battery discharges directly to meet household load, and never exports to the grid. The solar PV and battery installation allow the household to self-supply $84 \%$ of its electricity requirements and to draw no electricity at all from the grid during the typical $3-8 \mathrm{pm}$ network peak. For such a customer, a demand based tariff is likely to offer material benefits as such charges could be avoided almost entirely.

Table 3: Impact of solar PV and battery energy storage systems on customer grid requirements

\begin{tabular}{c|c|c|c|c}
\hline & \multicolumn{2}{|c|}{ Typical demand day } & \multicolumn{2}{c}{ Peak demand day } \\
\hline & $\begin{array}{c}\text { Daily grid } \\
\text { consumption } \\
(\mathrm{kWh})\end{array}$ & $\begin{array}{c}\text { Share of home } \\
\text { energy use from } \\
\text { grid }\end{array}$ & $\begin{array}{c}\text { Maximum } \\
\text { demand from } \\
\text { grid }(\mathrm{kW})\end{array}$ & $\begin{array}{c}\text { Maximum } \\
\text { export }(\mathrm{kW})\end{array}$ \\
\hline Grid only & 11.0 & $100 \%$ & 1.5 & - \\
\hline Solar PV (3 kW) & 5.7 & $52 \%$ & 1.2 & 1.5 \\
\hline $\begin{array}{c}\text { Solar PV and } \\
\text { energy storage } \\
(6 \mathrm{kWh})\end{array}$ & 1.3 & $12 \%$ & 0.7 & 0.9 \\
\hline
\end{tabular}

The variation in outcomes across solely grid-dependent households and those with solar PV or solar PV with storage is presented in Table 3. The utilisation of customer segmentation will allow unique customer consumption heterogeneity to be estimated and priced for the first time with the evolution of digital metering and distributed energy technologies. The share of energy from the grid declines significantly, indicating that distributed energy technologies are an emerging partialsubstitute for 'grid-supplied' electricity. In fact, prices may need to evolve to allow unique export profiles to be priced (for selling power to the grid) given the household's maximum demand of the grid may be facilitation of export on peak demand days.

Other technologies will naturally have different impacts on a household's load profile depending on their characteristics and how they are installed and used. For example, purchase of an electric vehicle will increase a household's overall energy consumption, with the exact impact on the load profile dependent on when it is charged. Home energy management systems and smart appliances can be programmed to optimise for self-consumption overall, or for a particular tariff structure (e.g. to shift demand to off-peak periods under a time-of-use or demand tariff).

The price dispersion analysis in Section 3 identified the practice of implicit second degree price discrimination, where customers with higher usage seek out and are offered discounted rates as compared to those with lower usage who may spend less time seeking out new offers presumably due to lower economic payoff for the utilisation of their time. Distributed energy technologies which very substantially lower grid-drawn energy supply, will amplify the natural heterogeneity of customer needs and preferences, and is thus likely to only increase the extent of price dispersion. It may also lessen the relevance of analyses which look only to unit price to determine value being delivered to customers by retail energy service providers. Some customers may begin to more heavily weight 'value-added' services over unit prices alone. These services

${ }^{17}$ Equivalent to a 7-8 kWh system with a depth of discharge around $80 \%$. 
might include an enhanced feed-in tariff, the ability to participate in peer-to-peer electricity trades, the availability of demand response products or the opportunity to be rewarded for provision of network and wholesale support services back to the system. As technology and energy services evolve it will become harder to perform a straight forward dispersion analysis as a standalone tool for assessing market competitiveness and any attendant consumer benefit or detriment.

It is positive that the retail regulatory and market framework is allowing new entrants with novel business models to enter the market and offer newly designed services to customers. By 'disrupting' the retail energy services market, new entrants drive enhanced competition amongst all market players. It will be important that governments reviewing retail electricity prices keep sight of the fast evolving consumer energy landscape and do not, in an attempt to protect consumers, propose a return to more rigid price-setting frameworks that have the unintended consequences of limiting the ability of both old and new market players to innovate their offerings in response to technology developments and changing consumer preferences.

However, it must also be recognised that the take-up of distributed energy technologies will be gradual and uneven. There will be households for whom the installation of distributed energy technologies is currently infeasible, whether due to financial strain, not owning their home or residing in a home unsuitable to these technologies. There will also remain customers who do not actively engage with the retail energy services market, whether through disinterest or difficulty in doing so. For these customers, competition on 'traditional' measures (e.g. unit pricing) remains very important. Further policy interventions may depend on the reasons for customer nonengagement. Measures to make engagement, at least at a basic level, simple and achievable are important for all customers. Vulnerable customers may require a more pro-active form of assistance to engage and realise the benefits of a competitive market. Competitive neutrality, encouraging a range of operators into the market to offer services meeting the broad spectrum of customer needs and preferences, is critical.

\section{Policy recommendations and concluding remarks}

This article considers retail competition within both a traditional framework of electricity being a homogenous good and the emerging framework of electricity being a heterogeneous suite of products and services. Our findings are relatively straightforward: the Victorian electricity market is exhibiting the characteristics of efficient pricing as the marginal unit is approximately priced at our estimate of marginal cost; implicit price discrimination is present with customers on the most price discounted products consuming significantly more energy than those on higher priced standing offers; and the temporally heterogeneous nature of electricity consumption will result in even greater price dispersion in future as new products and services allow heterogeneity to be targeted effectively for the first time.

The main policy recommendation that flows from these conclusions is that greater facilitation of competition by policy makers is warranted, rather than price interventions (as have occurred in the $\mathrm{UK}^{18}$ ). The analysis supports the conclusions of the eminent economists (Professors Yarrow, Vickers, Green, Littlechild, and Waddams Price) summarised by Simshauser and Whish-Wilson (2017) that reducing price discrimination is likely to reduce competition and have a detrimental impact on low-income customers.

\footnotetext{
${ }^{18}$ There is speculation that further intervention may occur - see http://www.cityam.com/263862/theresa-mays-conservatives-confirmplans-cap-energy-prices?utm_source=dlvr.it\&utm_medium=dvTwitter, Accessed online on 4 May 2017
} 
It is highly likely that price dispersion will become more pronounced as electricity markets decarbonise. Nelson et al (2017) demonstrate that increased proportions of renewables and battery storage will result in a higher proportion of supply chain costs being fixed rather than variable. As more costs become sunk, uniform pricing set to marginal cost will become even more problematic as large capital costs would not be recovered. As such, it is important that policy makers continue the push towards deregulated retail electricity markets to facilitate, rather than obstruct, the goals of efficient pricing and decarbonisation.

The benefits of competition are not just confined to price. The Grattan Institute (2017, p.22) summarises some of these non-pricing benefits by stating, 'Switching between retailers is now far easier and, in general, does not incur a cost to the consumer. Billing options have been expanded. E-billing is now available along with electronic payments. Some retailers will offer bill smoothing - paying the same or a similar amount every billing period - and can bill on a weekly basis. Call centres are now open for a longer period of time and retailers can communicate through the web and text messaging, while they have stopped door knocking.'

While our analysis indicates that the market is working effectively, it is important that governments promote regulatory frameworks that allow consumers to overcome the energy system's inherent complexity. This is particularly important as new tariffs and products and services enter the market. Sensible policy measures could include increased promotion of comparator tools such as Energy Made Easy ${ }^{19}$ and publication of easily understood 'standard energy bills' which discounted offers could be compared to. That said, innovation is more likely to be a better solution with information technology allowing customers to instantly compare complex pricing structures based upon their unique circumstances (discoverable through digital metering technology).

A key unresolved policy issue relates to operation of the retail market for customers in hardship. Simshauser and Nelson (2014) found that the 'family cohort' demographic is most prone to hardship given high household consumption and relatively low incomes per person. The data analysed in this paper supports this finding with 'hardship' customers consuming $40 \%$ more electricity than average. Currently, there is no requirement on energy companies to ensure that these customers are on the offer approximating marginal cost. While it would appear to be in the interests of the businesses themselves to do this (to minimise the prospect of bad debts), regulatory intervention could be considered in the event it is demonstrable that this is not occurring. ${ }^{20}$

\footnotetext{
${ }^{19}$ See www.energymadeeasy.gov.au, Accessed online on 3 May 2017.

${ }^{20}$ Emerging regulatory frameworks in Victoria and New South Wales require hardship customers to be on the 'best available offer'. There may also be arguments for increasing government intervention around 'credit screening' and other practices which result in customers being unable to secure offers from multiple companies. As electricity is an essential service, the benefits of competition rely upon customers being able to procure multiple offers.
} 


\section{References}

AUSGRID. (2015), 'Appendix 5: Price Elasticity of Demand', Submission to the AER, November.

Australian Energy Council: AEC. (2017), Solar Report, Available online at https://www.energycouncil.com.au/media/7687/australian-energy-council-solar-report march2017.pdf, Accessed online on 11 May 2017.

Australian Energy Council: AEC. (2016), Solar Report, Available online at https://www.energycouncil.com.au/media/7687/2016-06-30_australian-energy-council-solarreport-june-2016.pdf, Accessed online on 11 May 2017.

Bakke, G. (2016), The Grid - The Fraying Wires Between Our American Cities and Our Clean Energy Future, Bloomsbury Publishing.

Baumol, W. \& Swanson, D. (2003), 'The new economy and ubiquitous competitive price discrimination: Identifying defensible criteria of market power', Antitrust Law Journal, Vol. 70, No. 3, pp. 661-85.

Ben-David, R. (2017), 'Do discount wars benefit retail energy customers? Don't bet on it', Submission to the Review of Electricity and Gas Retail Markets in Victoria, Available online at http://www.delwp.vic.gov.au/ data/assets/pdf file/0011/378245/0.-Cover-letter-to-IndependentReview-of-Retail-Markets-in-Victoria.pdf, Accessed online on 12 May 2017.

Bloomberg New Energy Finance: BNEF. (2017), Australia Behind-the-Meter PV and Storage Forecast, BNEF Publication, 22 February 2017.

Borenstein, S. Rose, N. (1994), 'Competition and price dispersion in the U.S. airline industry', Journal of Political Economy, Vol. 102, No. 4, pp. 653-683.

Borenstein, S. (2009), 'To What Electricity Price Do Consumers Respond? Residential Demand Elasticity Under Increasing-Block Pricing', NBER Paper, Available at:

http://faculty.haas.berkeley.edu/borenste/download/NBER SI 2009.pdf, Accessed online on 19 October 2017.

Corts, K. (1998), 'Third-degree price discrimination in oligopoly: all-out competition and strategic commitment', RAND Journal of Economics, Vol. 29, No. 2, pp. 306-323.

Dana Jr, J.D. (1998), 'Advance-purchase discounts and price discrimination in competitive Markets', Journal of Political Economy, Vol. 106, No. 2, pp. 395-422.

Department of Environment, Land, Water and Planning: DELWP. (2017), Review of electricity and gas retail markets in Victoria, Victorian Government Publication, Melbourne.

ESC. (2002), 'Installing interval meters for electricity customers - costs and benefits', ESC Paper, November, ESC Victoria.

ESCOSA. (2004), 'Assessment of Demand Management and Metering Strategy Options', ESCOSA Report, Adelaide. 
Finkel, A. Moses, K. Munro, C. Effney, T. and O'Kane, M. (2016), Independent Review into the Future Security of the National Electricity Market: Preliminary Report, Commonwealth Government Publication, Canberra.

Flores M. and Waddams Price, C. (2013), 'Consumer behaviour in the British retail electricity market', Centre for Competition Policy Working Paper, No. 13-10, University of East Anglia.

Ghazizadeh, M.S. and Seifi, H. (2007), 'Electricity restructuring', IEEE Power and Energy Magazine, Vol. 5, pp. 16-20.

Grattan Institute. (2017), Price shock: Is the retail electricity market failing consumers?, Grattan Institute Publication, Melbourne.

Holmes, T. (1989), 'The effects of third-degree price discrimination in oligopoly', American Economic Review, Vol. 79, pp. 244-250.

Hviid, M. and Waddams Price, C. (2012), 'Non-discrimination clauses in the retail energy sector’, The Economic Journal, Vol 122, pp. F236-F252.

Independent Pricing and Regulatory Tribunal: IPART. (2015), IPART 2015 Household survey of electricity, gas and water usage, IPART Publication, Sydney.

Ito, K. (2012), 'Do Consumers Respond to Marginal or Average Price? Evidence from Nonlinear Electricity Pricing', American Economic Review, Vol. 104, No. 2, pp. 537-563.

Klein, B. (1993), 'Market power in antitrust: economic analysis after Kodak', Supreme Court Economic Review, Vol. 3, pp. 43-92.

Levine, M. E. (2002), 'Price discrimination without market power', Yale Journal on Regulation, Vol. 19, pp. 1-36.

Littlechild, S. (2014), 'Promoting or restricting competition? Regulation of the UK residential electricity market since 2008', EPRG Working Paper, No. 1415, University of Cambridge.

Littlechild, S. (2016), 'Contrasting developments in UK energy regulation', Economic Affairs, Vol. 36, No. 118-132.

Nelson, T. Bashir, S. McCracken-Hewson, E. and Pierce, M. (2017), 'The changing nature of the electricity industry', Economic Papers, In-press.

Nelson, T. and Reid, C. (2013), 'Reconciling energy prices and social policy', The Electricity Journal, Vol. 27, No. 1, pp. 104-114.

NIEIR, (2002), 'The price elasticity of demand for electricity in NEM regions', Report prepared for NEMMCO, June, Victoria.

Oakley Greenwood. (2017), Causes of residential electricity bill changes in Victoria, 1995 to 2017, Oakley Greenwood Publication, Melbourne.

Orton, F. Nelson, T. Pierce, M. and Chappel, T. (2017), 'Access Rights and Consumer Protections in a Distributed Energy System', in Innovation and Disruption at the Grids Edge, Elsevier. 
Pollit, M. and Haney, A. (2014), 'Dismantling a competitive retail electricity market', The Electricity Journal, Vol. 27, No. 1, pp. 66-73.

Pigou, A.C. (1920), The Economics of Welfare, Macmillan, London.

Ramsey, F. (1927), 'A contribution to the theory of taxation', The Economic Journal, Vol. 37, No. 145 , pp. $47-61$.

Reiss, P. and White, M. (2005), 'Household electricity demand, revisited', Review of Economic Studies, Vol. 73, No. 3, pp. 853-883.

Robinson, J. (1933). The Economics of Imperfect Competition, Macmillan, London.

Simshauser, P. and Downer, D. (2016), 'On the inequity of flat-rate electricity tariffs', The Energy Journal, Vol. 37, No. 3, pp. 199-229.

Simshauser, P. and Nelson, T. (2014), 'The Consequences of Retail Electricity Price Rises: Rethinking Customer Hardship', The Australian Economic Review, Vol. 47, No. 1, pp. 13-43.

Simshauser, P. and Whish-Wilson, P. (2017), 'Price discrimination in Australia's retail electricity markets: An analysis of Victoria \& Southeast Queensland', Energy Economics, In-press.

Stigler, G. (1987), A Theory of Price, Macmillan, New York.

Stole, L. (2007), 'Price discrimination and competition', In: Armstrong, M. Porter, R. (Eds.), Handbook of Industrial Economics vol. III, Elsevier, Amsterdam.

Taylor, C. (2003), 'Supplier Surfing: Competition and Consumer Behaviour in Subscription Markets', Rand Journal of Economics, Vol. 34, No. 2, pp. 223-246.

Varian, H. (1996), 'Differential pricing and efficiency', First Monday, Vol. 1, No. 2, pp. 1-13. 
Appendix 1: Distribution of AGL customer discounts in Victoria

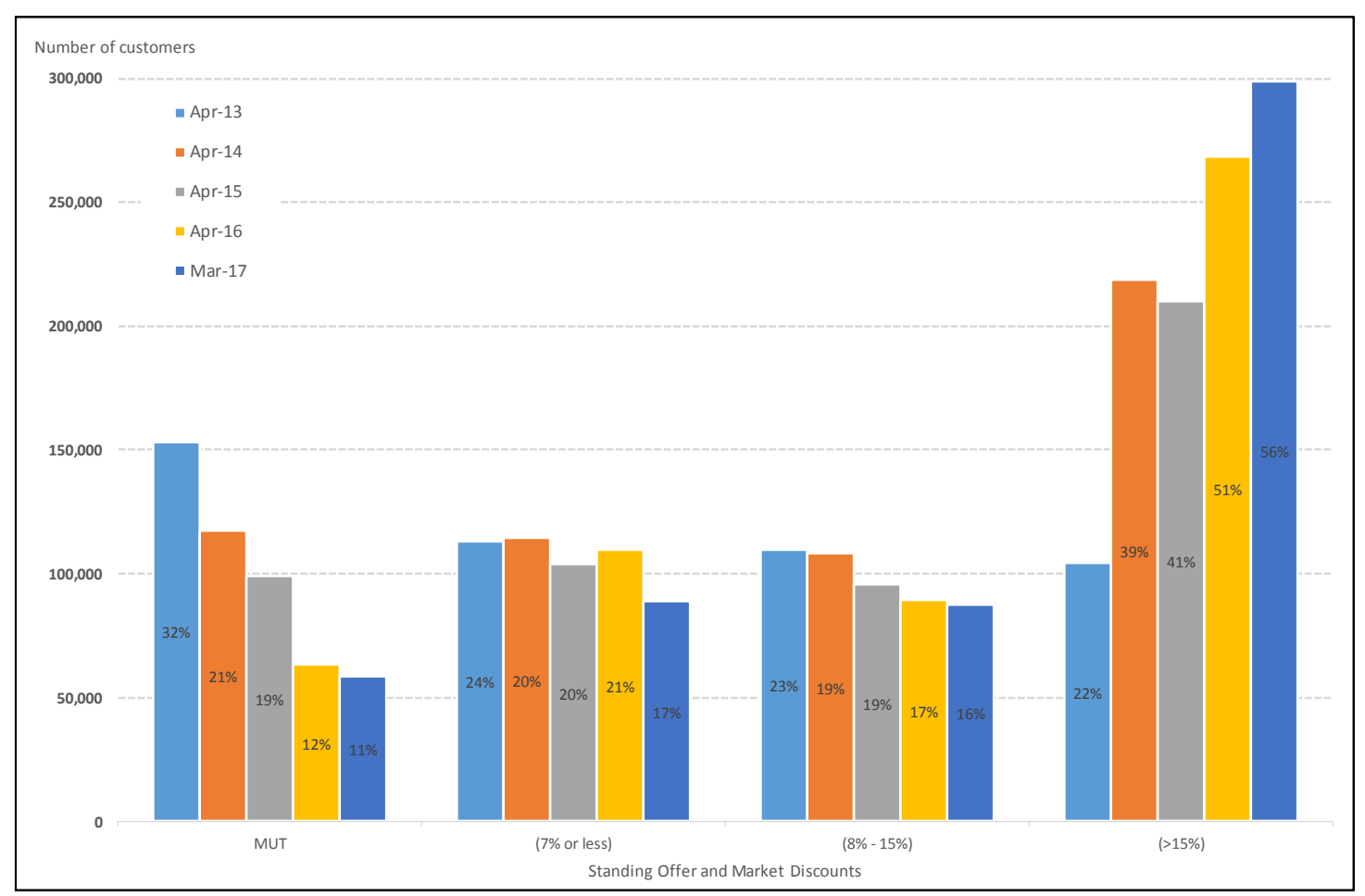


Appendix 2: Mean-difference tests

Non-concessions - standing offer and high discount

\begin{tabular}{lrr}
\hline & \multicolumn{1}{c}{ Variable 1 } & Variable 2 \\
\hline Mean & 10.52595726 & 12.81181147 \\
Variance & 70.6778085 & 66.54808709 \\
Observations & 1000 & 1000 \\
Hypothesized Mean & 0 & \\
Difference & 1996 & \\
df & & \\
$\mathrm{t} \mathrm{Stat}$ & -4.766908419 & \\
$\mathrm{P}(\mathrm{T}<=\mathrm{t})$ one-tail & $1.00295 \mathrm{E}-06$ & \\
$\mathrm{t}$ Critical one-tail & 1.645617395 & \\
$\mathrm{P}(\mathrm{T}<=\mathrm{t})$ two-tail & $2.0059 \mathrm{E}-06$ & \\
$\mathrm{t}$ Critical two-tail & 1.961153206 & \\
\hline
\end{tabular}

Concessions - standing offer and high discount

\begin{tabular}{lrr}
\hline & Variable 1 & Variable 2 \\
\hline Mean & 10.05700602 & 10.89217638 \\
Variance & 46.09257758 & 46.5394001 \\
Observations & 1000 & 1000 \\
Hypothesized Mean & 0 & \\
Difference & 1998 & \\
df & & \\
t Stat & -2.744066325 & \\
$\mathrm{P}(\mathrm{T}<=\mathrm{t})$ one-tail & 0.00306129 & \\
$\mathrm{t}$ Critical one-tail & 1.64561663 & \\
$\mathrm{P}(\mathrm{T}<=\mathrm{t})$ two-tail & 0.00612258 & \\
$\mathrm{t}$ Critical two-tail & 1.961152015 & \\
\hline
\end{tabular}

